\title{
Different Localization and Regulation of Two Types of Vasopressin Receptor Messenger RNA in Microdissected Rat Nephron Segments Using Reverse Transcription Polymerase Chain Reaction
}

\author{
Yoshio Terada, Kimio Tomita, Hiroshi Nonoguchi, Tianxin Yang, and Fumiaki Marumo \\ Second Department of Internal Medicine, Tokyo Medical and Dental University, Tokyo, 113, Japan
}

\begin{abstract}
Recent studies have revealed that arginine vasopressin (AVP) has at least two types of receptors in the kidney: V1a receptor and $V 2$ receptor. In this study, microlocalization of mRNA coding for V1a and V2 receptors was carried out in the rat kidney using a reverse transcription and polymerase chain reaction. Large signals for V1a receptor PCR product were detected in the glomerulus, initial cortical collecting duct, cortical collecting duct, outer medullary collecting duct, inner medullary collecting duct, and arcuate artery. Small but detectable signals were found in proximal convoluted and straight tubules, inner medullary thin limbs, and medullary thick ascending limbs. Large signals for $\mathrm{V} 2$ receptor $\mathrm{mRNA}$ were detected in the cortical collecting duct, outer medullary collecting duct, and inner medullary collecting duct. Small signals for V2 receptor were found in the inner medullary thick limbs, medullary thick ascending limbs, and initial cortical collecting duct. Next, we investigated $\mathrm{V} 1 \mathrm{a}$ and $\mathrm{V} 2$ receptor mRNA regulation in the dehydrated state. During a 72-h water restriction state, the plasma AVP level increased and V2 receptor mRNA decreased in collecting ducts. In contrast, V1a receptor $m R N A$ did not change significantly. Thus, the two AVP receptor subtypes are distributed differently along the nephron, and these mRNAs are regulated differently in the dehydrated state. (J. Clin. Invest. 92:2339-2345.) Key words: reverse transcription • polymerase chain reaction • messenger RNA • glomerulus • inner medullary collecting duct
\end{abstract}

\section{Introduction}

The antidiuretic hormone arginine vasopressin (AVP) ${ }^{1}$ is known to influence the glomerular function and to increase the water permeability of the collecting duct and it has also been shown to act on other nephron segments, in the mammalian kidney $(1,2)$. AVP receptors are $G$ protein-coupled and have

Address correspondence and reprint requests to Yoshio Terada, M.D., Second Department of Internal Medicine, Tokyo Medical and Dental University, 5-45, Yushima 1-chome, Bunkyo-ku, Tokyo 113, Japan.

Received for publication 18 December 1992 and in revised form 30 June 1993.

1. Abbreviations used in this paper: AVP, arginine vasopressin; iCCD, initial cortical collecting duct; IMCD, inner medullary collecting duct; IMTL, inner medullary thin limb; MTAL, medullary thick ascending limb; OMCD, outer medullary collecting duct; PCT, proximal converted tubule; PST, proximal straight tubule; RT-PCR, reverse transcription PCR.

J. Clin. Invest.

(c) The American Society for Clinical Investigation, Inc.

0021-9738/93/11/2339/07 \$2.00

Volume 92, November 1993, 2339-2345 been divided into at least three types: V1a (vascular/hepatic) and V1b (anterior pituitary) receptors, which act through phosphatidylinositol hydrolysis to mobilize intracellular $\mathrm{Ca}^{2+}$; and V2 (kidney) receptor, which is coupled to adenylate cyclase (3). Recently, V1a and V2 receptor cDNAs were cloned (4-6). These cDNAs encode proteins with seven putative transmembrane domains and a similar structure to rhodopsin and other $G$ protein-coupled receptors (4-6).

The distribution of $\mathrm{V} 1 \mathrm{a}$ and $\mathrm{V} 2$ receptors in the kidney has been investigated by binding studies (7-11) and many physiological studies (12-17). The presence of V2 receptor in the collecting duct is well established $(9,11,18)$. However, in MTAL and glomerulus, the presence of $\mathrm{V} 2$ receptor is controversial. It is also not well clarified whether V2 receptor is expressed or not in IMTL and the renal vascular system.

Recently, some reports revealed that V1a receptor is expressed in the glomerular mesangial cell $(19), \operatorname{CCD}(11,16)$, OMCD (11), and IMCD (11). Ando et al. reported that AVP action from the apical side may be mediated via $\mathrm{V} 1 \mathrm{a}$ receptor in rabbit $C C D(20)$. On the other hand, binding studies could not detect Vla binding sites in glomerulus (7-10). Thus, the presence of V1a receptor in the kidney is still controversial. To understand clearly the physiological function of AVP in the kidney, it seems very important to know the precise localization of both types of receptor expressions along the nephron segments and in the renal vascular system.

AVP plays critical roles in maintaining body homeostasis in water restricted conditions. In the dehydrated state, the plasma AVP level increases and water and solute are reabsorbed in the collecting ducts $(21,22)$. Downregulation or desensitization of AVP receptor have been reported when the plasma AVP level increases $(23,24)$. The mechanism of this phenomenon is not well known. It has not been well investigated which type of receptor is regulated by the plasma AVP level. Therefore, we investigated the regulations of mRNA expressions of $\mathrm{V} 1 \mathrm{a}$ and $\mathrm{V} 2$ receptors in water restricted rats.

Recently, Moriyama et al. (25) and Terada et al. (26) introduced a new method for measurement of relative levels of specific mRNA in single microdissected renal tubules, using the PCR coupled to reverse transcription (RT-PCR). Using this technique, relative quantitation of $m R N A$ coding for peptide hormone receptor was performed from only $2-\mathrm{mm}$ lengths of renal tubules (26).

In the present study, we used the RT-PCR technique for the precise localization and regulation of $\mathrm{V} 1 \mathrm{a}$ and $\mathrm{V} 2$ receptor mRNAs in microdissected renal tubules, glomeruli, and arcuate arteries.

\section{Methods}

Renal tubule microdissection. After previously described techniques (26), male Sprague-Dawley rats weighing $75-100 \mathrm{~g}$ were killed by de- 
capitation. The aorta was cannulated with polyethylene tubing below the left kidney, and the left kidney was perfused in vivo. The kidney was perfused initially with $10 \mathrm{ml}$ of ice-cold dissection solution (solution 1) and then with $10 \mathrm{ml}$ of the same solution containing $1 \mathrm{mg} / \mathrm{ml}$ collagenase (collagenase solution) (type I, $300 \mathrm{U} / \mathrm{mg}$; Sigma Chemical Co., St. Louis, MO) and $1 \mathrm{mg} / \mathrm{ml}$ bovine serum albumin (Sigma Chemical Co.). The dissection solution (solution 1) contained the following (in mM): $135 \mathrm{NaCl}, 1 \mathrm{Na}_{2} \mathrm{SO}_{4}, 1.2 \mathrm{MgSO}_{4}, 5 \mathrm{KCl}, 2 \mathrm{CaCl}_{2}, 5.5$ glucose, and $5 \mathrm{~N}$-2-hydroxyethylpiperazine- $N^{\prime}$-2-ethanesulfonic acid (Hepes) ( $\mathrm{pH}$ 7.4). The left kidney was removed and a coronal section was made that contained the entire corticopapillary axis. This section was cut into three pieces: cortex, outer medulla, and inner medulla. These pieces were transferred into individual tubes containing $1 \mathrm{ml}$ of the same collagenase solution that was used to perfuse the kidney. The tubes were incubated for $30 \mathrm{~min}$ (cortex and outer medulla) or $40 \mathrm{~min}$ (inner medulla) at $37^{\circ} \mathrm{C}$ in a shaking water bath. The solutions were bubbled with $100 \%$ oxygen during these incubations. Then tissues were transferred to the dissection solution containing $10 \mathrm{mM}$ vanadyl ribonucleotide complex (Life Technologies, Inc., Gaithersburg, MD), a potent RNase inhibitor, and they were placed on ice until microdissection.

After previously described techniques (26), we microdissected the following structures: glomeruli $(\mathrm{Glm})$, proximal convoluted tubule (PCT), proximal straight tubule (PST), inner medullary thin limb (IMTL), outer medullary thick ascending limb (MTAL), initial cortical connecting ducts (iCCD), cortical collecting ducts (CCD), outer medullary collecting duct (OMCD), inner medullary collecting duct (IMCD), and arcuate artery. Generally, five glomeruli or $2-\mathrm{mm}$ lengths of the renal tubule segments or arcuate arteries were transferred to each assay tube, as indicated. The reason why we took five Glm as one sample is based on the protein contents. The protein contents of five $\mathrm{Glm}$ is $185.3 \pm 14.7 \mathrm{ng}(n=5$, mean $\pm \mathrm{SEM})$ is approximately equal to the protein contents of 2-mm of IMCD (27). The protein level of Glm was determined using protein assay reagent (Bio-Rad Laboratories, Richmond, CA).

Microdissected tubules, glomeruli, arcuate arteries were washed free of contaminating debris and vanadyl ribonucleotide complex in separate wash dishes. These structures were transferred into appropriate RT-PCR reaction tubes, which contained $10 \mu$ l of ice-cold dissection solution containing $>1 \mathrm{U} / \mu \mathrm{l}$ of human placental RNase inhibitor (Boehringer-Mannheim GmbH., Mannheim, Germany) and 5 $\mathrm{mM}$ dithiothreitol (Sigma Chemical Co.).

Reverse transcription. RT was performed using a cDNA synthesis kit (Boehringer-Mannheim GmbH.). The RNase-inhibitor solution was removed, and $9 \mu \mathrm{l}$ of $2 \%$ Triton X-100, containing $>1 \mathrm{U} / \mu \mathrm{l}$ of RNase-inhibitor, $5 \mathrm{mM}$ DTT, and 3 U RNase-free DNase (Pharmacia Fine Chemicals, Piscataway, NJ), was added to permeabilize the cells, followed by incubation at $37^{\circ} \mathrm{C}$ for $30 \mathrm{~min}$ to digest the genomic DNA. The samples were heated to $90^{\circ} \mathrm{C}$ for $5 \mathrm{~min}$ to inactivate the DNase. RT components were added to the reaction tubes as described previously (26): $4 \mu \mathrm{l}$ of buffer I, $1 \mu \mathrm{l}$ of RNase inhibitor, $2 \mu \mathrm{l}$ of deoxynucleotide mixture, $2 \mu \mathrm{l}$ of random primer, and $2 \mu \mathrm{l}$ of avian myeloblastoma virus reverse transcriptase. Reaction tubes were incubated at $42^{\circ} \mathrm{C}$ for $60 \mathrm{~min}$ in the Programmed Tempcontrol System (Astec, Tokyo, Japan). At the end of the incubation period, the reaction was stopped by heating at $90^{\circ} \mathrm{C}$ for $5 \mathrm{~min}$. This heat treatment also denatures RNAcDNA hybrids and inactivates the reverse transcriptase. Then the reaction tubes were placed on ice until the addition of PCR reagents.

Polymerase chain reaction. PCR was performed using the GeneAmp DNA Amplification Reagent Kit (Perkin-Elmer Cetus, Norwalk, $\mathrm{CT}$ ), with rat V1a and V2 receptor specific primers prepared on a DNA synthesizer (Applied Biosystems Inc., Tokyo, Japan). We designed specific primers $20-25$ nucleotides in length with $50-60 \%$ GC composition. The resultant high calculated melting temperature $\left(>75^{\circ} \mathrm{C}\right)$ allows a stringent annealing temperature in the PCR cycle. V la receptor primer 1 (antisense) was defined by bases 579-598, and primer 2 (sense) encompassed bases 1-21 (4). The sequence of Vla primer 1 was 5'-TAGTGCCATTGTTCACCTCG-3', primer 2 was 5'-ATGAGTTTCCCGCGAGGCTCC-3'. The predominant cDNA amplification product was predicted to be 598 bp in length (the distance between primers plus primer length). A third oligonucleotide was synthesized to serve as an amplification product-specific probe. This oligonucleotide (sense) included bases 444-463 of the cDNA, positioned between primer 1 and primer 2 . The sequence of this oligonucleotide probe was 5'-TACATCGCCGTGTGCCACCC-3'.

V2 receptor primer 1 (antisense) was defined by bases $581-600$, and primer 2 (sense) encompassed bases -24 to $-3(6)$. The sequence of V2 receptor primer 1 was 5'-CCATGGTTCTGCAAATCGGG-3', primer 2 was 5'-TAGGTCATCATCAACCACCCCA-3'. The predominant $\mathrm{CDNA}$ amplification product was predicted to be $625 \mathrm{bp}$ in length. A third oligonucleotide was synthesized to serve as an amplification product-specific probe. This oligonucleotide (sense) included bases 307-326 of the cDNA, positioned between primer 1 and primer 2 . The sequence of this oligonucleotide probe was 5'-ACCGCTTCCATGGCCCTGAT- 3 '.

RT and PCR of GAPDH served as a positive control. The primers were defined by the following cDNA base sequences (28): primer 1 (antisense), bases 794-813, sequence, 5'-AGATCCACAACGGATACATT-3'; primer 2 (sense), bases 506-525, sequence, 5'-TCCCTCAAGATTGTCAGCAA-3'. The cDNA amplification product was predicted to be $309 \mathrm{bp}$ in length. A third oligonucleotide was synthesized to serve as an amplification product-specific probe. This oligonucleotide (sense) included bases 307-326 of the cDNA, positioned between primer 1 and primer 2 . The sequence of this oligonucleotide probe was 5'-ACCGCTTCCATGGCCCTGAT-3'. When we used GAPDH as an internal control primer, after reverse transcription, we divided $20 \mu \mathrm{l}$ samples into $15 \mu \mathrm{l}$ for V1a or V2 receptor and $5 \mu \mathrm{l}$ for GAPDH. The volume was adjusted to $20 \mu \mathrm{l}$ with sterile water. Then we ran parallel PCR reactions with each set of primers.

To carry out the PCR, $80 \mu \mathrm{l}$ of a PCR master mix was added to each tube directly. $50 \mathrm{pmol}$ of each of primers 1 and 2 was used per reaction for both V1a and V2 receptor. Deoxynucleotides were added to a final concentration of $0.20 \mathrm{mM}$ each. Reaction buffer $(10 \times)$ was diluted $(1 / 10)$ to have a final composition of: $10 \mathrm{mM}$ Tris- $\mathrm{HCl}, \mathrm{pH} 8.3,50 \mathrm{mM}$ $\mathrm{KCl}, 1.5 \mathrm{mM} \mathrm{MgCl}_{2}$, and $0.001 \%$ (wt/vol) gelatin, $2.5 \mathrm{U}$ of Taq DNA polymerase.

$100 \mu \mathrm{l}$ of mineral oil was overlayed to prevent evaporation during the high temperature incubations. The tubes were placed in the Programmed Tempcontrol System programmed as follows. First, incubation at $94^{\circ} \mathrm{C}$ for $3 \mathrm{~min}$ (initial melt). Then, 30 cycles of the following sequential steps: $94^{\circ} \mathrm{C}$ for $1 \mathrm{~min}$ (melt), $60^{\circ} \mathrm{C}$ for $1 \mathrm{~min}$ (anneal), and $72^{\circ} \mathrm{C}$ for $3 \mathrm{~min}$ (extend). And last, incubation at $72^{\circ} \mathrm{C}$ for $7 \mathrm{~min}$ (final extension). Then samples were kept at $4^{\circ} \mathrm{C}$ until the time of analysis.

$P C R$ product analysis. $90 \mu \mathrm{l}$ of the total reaction volume was ethanol precipitated (29). The PCR products were size-fractionated by $2 \%$ agarose gel electrophoresis. After electrophoresis and ethidium bromide staining, DNA bands were visualized with an ultraviolet transilluminator (Funakoshi, Tokyo, Japan).

For Southern blot analysis, gels were blotted onto a nitrocellulose filter (Funakoshi) essentially as described by Maniatis et al. (29). The synthetic oligonucleotide probes were end-labeled with ${ }^{32} \mathrm{P}$ as described previously (26). Prehybridization/hybridization washes were also the same as previously described (26).

To confirm that the $P C R$ products were really $\mathrm{V} 1 \mathrm{a}$ and $\mathrm{V} 2$ receptor cDNAs, the PCR products were sequenced. PCR products from glomeruli were separated by gel electrophoresis. PCR products of $\mathrm{V} 1 \mathrm{a}$ and V2 receptors were subcloned into pGEM-3Zf $(-)$ vector (Promega Biotec, Madison, WI) as described by Finney (30). We cut pGEM$3 \mathrm{Zf}(-)$ vector at SamI site, and thymine was attached at $3^{\prime}$ end using Taq DNA polymerase (Perkin-Elmer Cetus), because Taq DNA polymerase has terminal transferase activity. The PCR product has adenine in its $3^{\prime}$ end. We ligated PCR products and pGEM-3Zf $(-)$, then sequenced using the dideoxynucleotide chain termination reaction of Sanger et al. (31). 
Relative-quantitation of $m R N A$ levels from autoradiographs. The relative amount of PCR products was determined by densitometer scanning of autoradiographs using a laser densitometer (Hoefer Scientific Instruments, Inc., San Francisco, CA ). For relative quantitation, we used the densitometry value from the $2 \mathrm{~mm}$ of same nephron segments, and adjusted the densitometry values with the GAPDH band intensity.

To test the relationship between the quantity of starting material and that of amplification product as reflected by densitometry values, we compared amplification products from several lengths of renal tubules. We compared amplification products from several lengths of OMCD $(0.2-2.0 \mathrm{~mm}, n=12)$ for V la receptor and IMCD $(0.2-2.0$ $\mathrm{mm}, n=12$ ) for $\mathrm{V} 2$ receptor. Linear regression analysis showed high correlation between densitometry values and the length of each tubule for V1a receptor $(r=0.95)$ and V2 receptor $(r=0.95)$ (data not shown).

Water restriction experiments. The water restricted experiments were performed using male Sprague-Dawley rats weighing 75-100 $\mathrm{g}(n$ $=6$ per group). The normal rat group was given a standard diet and allowed free access to tap water. The dehydration experiment group was deprived of water for $6,12,24,48$, and $72 \mathrm{~h}$ before death. The rats were anesthetized intraperitoneally with pentobarbital sodium (50 $\mathrm{mg} / \mathrm{kg}$ ) and the blood samples were taken from the heart. Plasma AVP was measured by radioimmunoassay with specific AVP antibody (AVP-RIA kits, Mitsubishiyuka, Tokyo, Japan) as previously described (32). Briefly, the purification process is as follows: SepPak C18 cartridges (Waters Associates, Milford, MA) were prewetted with 10 $\mathrm{ml}$ methanol. A 1-ml plasma sample is acidified with $0.1 \mathrm{~N} \mathrm{HCl}$ and applied to the column dropwise. The cartridge is rinsed with $10 \mathrm{ml} 4 \%$ acetic acid, and then AVP is eluted with $1.5 \mathrm{ml}$ ethanol. The samples were evaporated and then reconstituted with $1 \mathrm{ml}$ of assay buffer ( 50 $\mathrm{mM}$ phosphate buffer [ $\mathrm{pH} 7.4]$ containing $0.2 \%$ bovine serum albumin and $10 \mathrm{mM}$ EDTA). The radioimmunoassay was carried out with specific AVP antibody as indicated in the kits. Plasma osmolality was measured with a vapor pressure osmometer (Wescor Inc., Logan, UT). The band intensity of V1a and V2 receptor was adjusted by the GAPDH band intensity of the same lane.

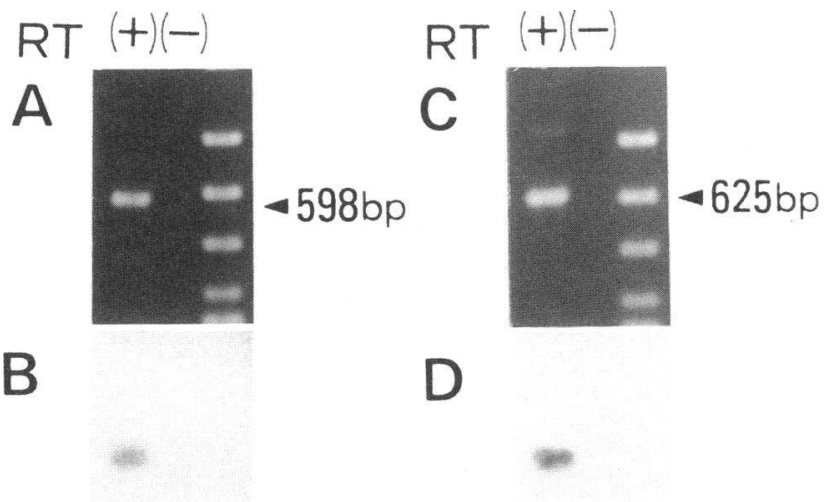

Figure 1. Effect of RT on V1a and V2 receptor mRNAs amplification. The PCR amplification ( 30 cycles) was performed from $2 \mathrm{~mm}$ of OMCD for V1a receptor or IMCD for V2 receptor with and without reverse transcription. $(A)$ Ethidium bromide-stained agarose gels for V la receptor. $(B)$ Autoradiograms of corresponding Southern blots. The blots were probed with a ${ }^{32} \mathrm{P}$-labeled oligonucleotide that localized between the Vla receptor primers. $(C)$ Ethidium bromidestained agarose gels for $\mathrm{V} 2$ receptor. $(D)$ Autoradiograms of corresponding Southern blots. The blots were probed with a ${ }^{32} \mathrm{P}$-labeled oligonucleotide that localized between the $\mathrm{V} 2$ receptor primers.

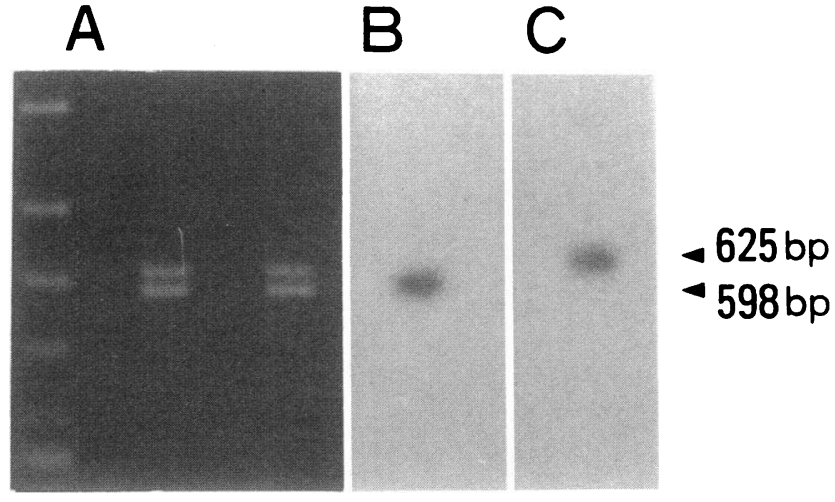

Figure 2. Specificity of V1a and V2 probes to PCR products. ( $A$ ) PCR products amplified from OMCD in the presence of both V1a and V2 receptor primers ( 30 cycles of PCR amplification). ( $B$ ) Southern hybridization with ${ }^{32} \mathrm{P}$-labeled V la probe to 598 -bp band. $(C)$ Southern hybridization with ${ }^{32} \mathrm{P}$-labeled V2 probe to 625 -bp band.

Statistics. The results were given as mean \pm SEM. The differences were tested using analysis of variance. $P<0.05$ was considered significant.

\section{Results}

Effect of reverse transcription on VIa and $V 2$ receptor $m R N A s$ amplification (Fig. 1). With reverse transcription, we detected a clear single band, which was the predicted size of $598 \mathrm{bp}$ for V1a receptor from OMCD (Fig. 1, $A$ and $B$ ), and we also detected a clear single band, which was the predicted size of 625 bp for V2 receptor from IMCD (Fig. 1, $C$ and $D$ ). When the PCR procedure was carried out in the absence of reverse transcriptase, the 598-bp band and the 625-bp band were not seen, and there was no other recognizable band. This indicated that the 598-bp and the 625-bp bands originated from mRNA, not from genomic DNA, which was presumably digested by DNase treatment. The Southern blots of the gels demonstrated that $\mathrm{V} 1$ a specific probe binds to the 598 -bp product, and V2 specific probe binds to the 625 -bp product, confirming their identity.

Specificity of VIa and V2 probes to PCR products (Fig. 2). We performed PCR amplification in the presence of both V1a and V2 receptor primers from OMCD. As shown in Fig. $2 A$, the 598-bp band and 625-bp band are clearly distinguished in $2 \%$ agarose gel. $\mathrm{V} 1$ a probe hybridized to the 598 -bp band specifically and did not hybridize to 625 -bp band (Fig. $2 \mathrm{~B}$ ). V2 probe hybridized to 625 -bp band specifically and did not hybridize to 598 -bp band (Fig. $2 C$ ).

Distribution of V1a and $V 2$ receptors $m R N A s$ in microdissected structures (Fig. 3). Each reaction was performed using either 2-mm of tubule length, five glomeruli, or 2-mm length of arcuate artery. A single band of predicted size ( $598 \mathrm{bp}$ ) was consistently found from Glm, iCCD, CCD, OMCD, IMCD, and arcuate artery (Fig. $3 \mathrm{~A}$ ). A faint but detectable band was found from PCT, PST, IMTL, and MTAL (Fig. $3 B$ ). The Southern blots of the gels demonstrated specific binding of the oligonucleotide probe to the 598 -bp product (Fig. $3 \mathrm{~B}$ ). We confirmed that the PCR product had an identical sequence to V la receptor cDNA by sequencing the subcloned PCR product. The largest signal for V1a receptor was detected in Glm. 


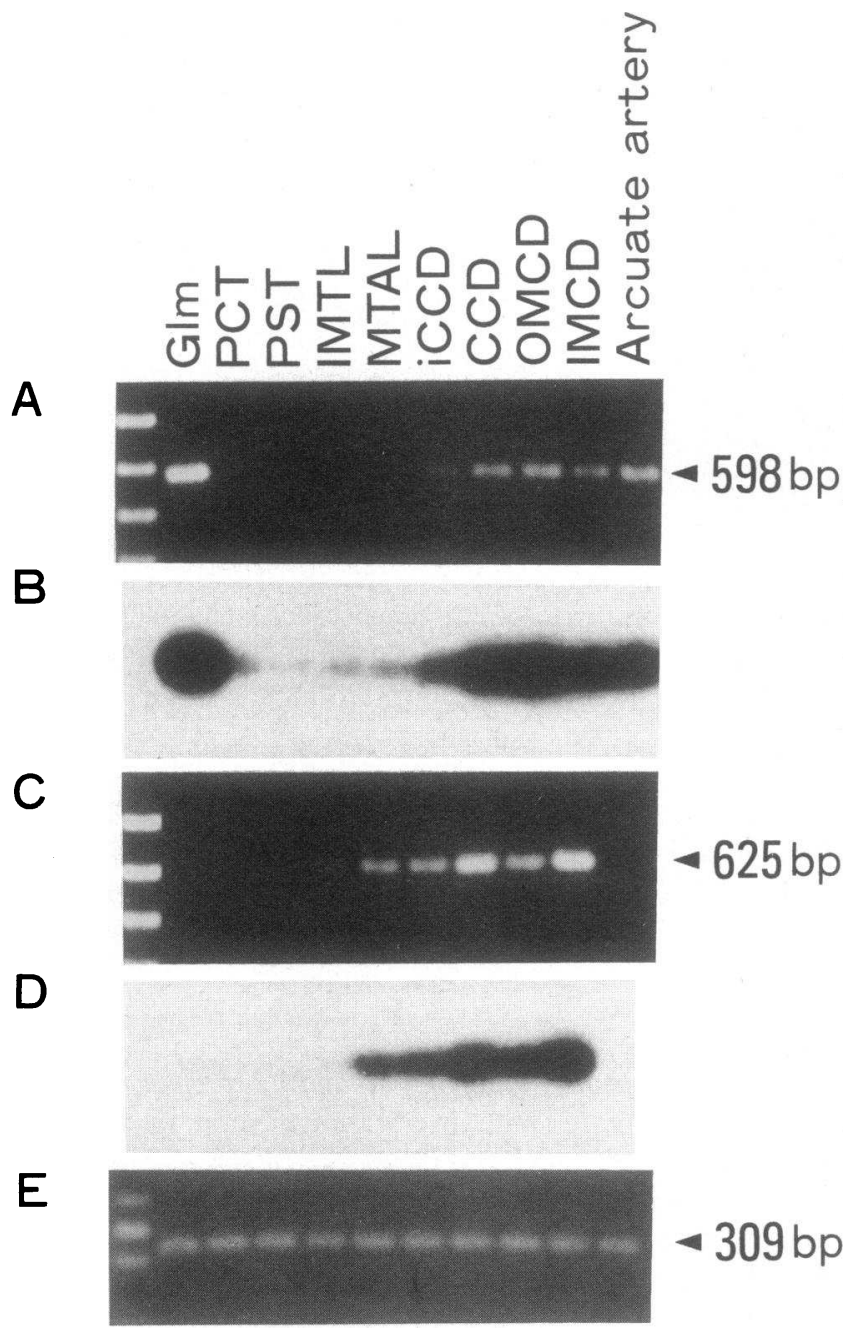

Figure 3. Detection of V1a and V2 receptors mRNAs in microdissected renal structures by RT-PCR. Each PCR amplification ( 30 cycles) was performed using either $2 \mathrm{~mm}$ of renal tubule, five glomeruli, or $2 \mathrm{~mm}$ length of arcuate artery. $(A)$ Ethidium bromide-stained agarose gels for V1a receptor. The arrow indicates expected PCR product size ( $598 \mathrm{bp}$ ). (B) Autoradiograms of corresponding Southern blots for V1a receptor. The blots were probed with a ${ }^{32} \mathrm{P}$-labeled oligonucleotide that localized between the PCR primers. $(C)$ Ethidium bromide-stained agarose gels for $\mathrm{V} 2$ receptor. The arrow indicates expected PCR product size ( $625 \mathrm{bp})$. (D) Autoradiograms of corresponding Southern blots for V2 receptor. The blots were probed with a ${ }^{32} \mathrm{P}$-labeled oligonucleotide that localized between the PCR primers. $(E)$ Ethidium bromide-stained agarose gel of GAPDH as positive control primers. The arrow indicates expected PCR products size ( $309 \mathrm{bp}$ ).

Large signals were detected in $\mathrm{OMCD}, \mathrm{CCD}, \mathrm{IMCD}$, iCCD, and arcuate artery.

A single band for $\mathrm{V} 2$ receptor mRNA was consistently found from IMCD, OMCD, CCD, iCCD, MTAL, and IMTL (Fig. $3 C$ ). This band was the predicted size $(625 \mathrm{bp})$. The Southern blots of the gels demonstrated specific binding of the oligonucleotide probe to the $625-\mathrm{bp}$ product (Fig. $3 \mathrm{D}$ ). We confirmed that PCR product had an identical sequence to V2 receptor cDNA by sequencing the subcloned PCR product. Among renal tubule segments, the largest signal was consis- tently found in IMCD. Furthermore, large signals were consistently seen in CCD, OMCD, iCCD, and MTAL. A small but detectable band was observed from IMTL. We could not detect a band from Glm, PCT, PST, or arcuate artery. The amplification product of GAPDH was detected from all renal structures at the predicted size ( $309 \mathrm{bp}$ ) and served as a positive control for the RT-PCR reaction (Fig. $3 E$ ). We obtained similar results for V1a and V2 receptors from five experiments of five rats.

$V 1 a$ and $V 2$ receptor $m R N A$ regulation by dehydration in rat glomeruli and collecting ducts (Fig. 4). The state of dehydration of the rats was evaluated by comparing plasma osmolality and plasma AVP concentration among the two groups. Plasma osmolality was significantly elevated in the 72-h water restricted animals $(306 \pm 2.5 \mathrm{mosmol} / \mathrm{kg})$ compared with control values $(290 \pm 1.1 \mathrm{mosmol} / \mathrm{kg})(P<0.05)$. Plasma AVP levels also were significantly increased, at 23.4-fold, in animals in the 72-h water restricted group $(77.5 \pm 17.4 \mathrm{pg} / \mathrm{ml})$ compared with control values $(3.3 \pm 0.9 \mathrm{pg} / \mathrm{ml})$. V1a receptor expressions did not significantly change between the two groups in glomeruli and collecting ducts (Fig. 4, $A$ and $B$ ). On the other hand, V2 receptor mRNA expressions in collecting ducts decreased in water restricted rats (Fig. $4, D$ and $E$ ). In CCD of water restricted rats, PCR products for V2 receptor mRNA decreased to $58.5 \pm 8.2 \%$ of the PCR products of normal rat group. In OMCD and IMCD the signals for V2 receptor mRNA reduced to $67.1 \pm 9.4 \%$ and $42.3 \pm 11.0 \%$ of the normal rat group in water restricted rats, respectively. The values were corrected by the band intensity of GAPDH band intensity of the same sample.

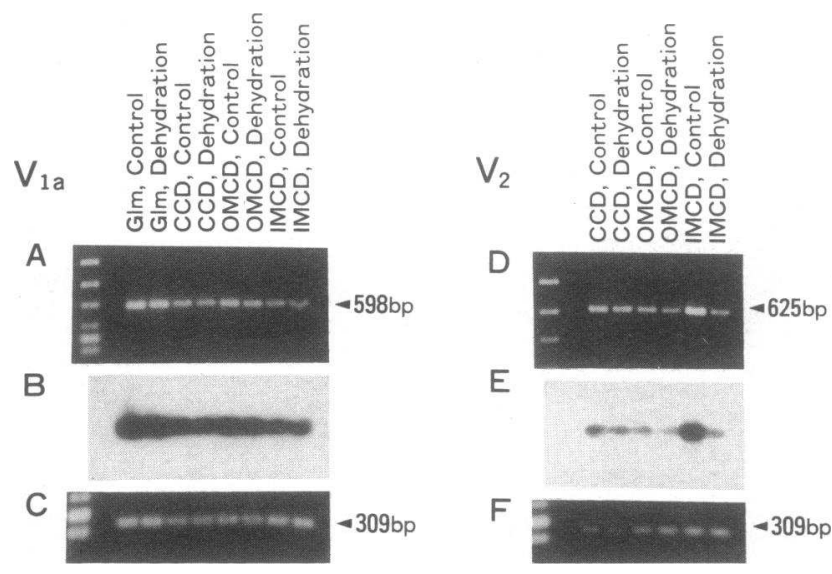

Figure 4. Effects of dehydration on V1a and V2 receptor mRNA expression in nephron segments. Each PCR amplification ( 30 cycles) was performed using either $2 \mathrm{~mm}$ of renal tubule. $(A)$ Ethidium bromide-stained agarose gels for $\mathrm{V} l \mathrm{l}$ receptor from control and dehydrated rats nephron segments. The arrow indicates expected PCR product size $(598 \mathrm{bp})$. (B) Autoradiograms of corresponding Southern blots for V1a receptor. $(C)$ Ethidium bromide-stained agarose gel of GAPDH as positive control primers. The arrow indicates expected PCR products size ( $309 \mathrm{bp}$ ). ( $D$ ) Ethidium bromide-stained agarose gels for $\mathrm{V} 2$ receptor from control and dehydrated rats nephron segments. The arrow indicates expected PCR product size $(625 \mathrm{bp})$. ( $E$ ) Autoradiograms of corresponding Southern blots for V2 receptor. $(F)$ Ethidium bromide-stained agarose gel of GAPDH as positive control primers. The arrow indicates expected PCR products size (309-bp). 

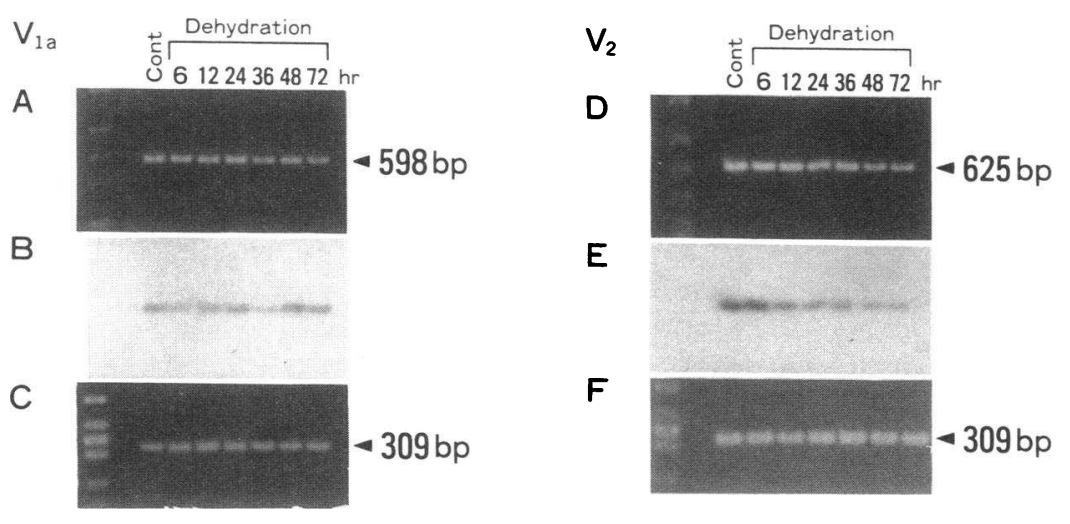

Figure 5. Time course on V1a and V2 receptor mRNA expression in IMCD during dehydration. Each PCR amplification ( 30 cycles) was performed using either $2 \mathrm{~mm}$ of renal tubule. $(A)$ Ethidium bromide-stained agarose gels for Vla receptor from IMCD of control and dehydrated rats. The arrow indicates expected PCR product size ( $598 \mathrm{bp}$ ). ( $B$ ) Autoradiograms of corresponding Southern blots for Vla receptor. $(C)$ Ethidium bromide-stained agarose gel of GAPDH as positive control primers. The arrow indicates expected PCR products size (309 bp). (D) Ethidium bromide-stained agarose gels for V2 receptor from IMCD of control and dehydrated rats. The arrow indicates expected $P C R$ product size ( $625 \mathrm{bp}$ ). $(E)$ Autoradiograms of corresponding Southern blots for V2 receptor. $(F)$ Ethidium bromide-stained agarose gel of GAPDH as positive control primers. The arrow indicates expected PCR products size ( $309 \mathrm{bp}$ ).

Time course of V2 and V1a receptor expression in IMCD during dehydration (Fig. 5). Plasma osmolality was significantly elevated from 24 -h water restriction ( $299 \pm 2.5 \mathrm{mosmol} /$ $\mathrm{kg})$ compared with control values $(290 \pm 1.1 \mathrm{mosmol} / \mathrm{kg})(n$ $=5$, mean \pm SEM, $P<0.05$ ). Plasma AVP levels were also increased from control values $(3.3 \pm 0.9 \mathrm{pg} / \mathrm{ml})$ as follows: $(10.7 \pm 2.5)$ at $6 \mathrm{~h},(37.5 \pm 5.2)$ at $12 \mathrm{~h},(44.0 \pm 3.8)$ at $24 \mathrm{~h}$, $(52.3 \pm 8.5)$ at $36 \mathrm{~h},(58.5 \pm 10.3)$ at $48 \mathrm{~h}$, and $(88.5 \pm 19.2)$ at 72 $\mathrm{h}$ in water restricted rats. V1a receptor expressions did not significantly change during experiments in IMCD (Fig. 5, $A$ and $B)$. On the other hand, V2 receptor mRNA expressions in IMCD decreased from 12-h water restriction and gradually decreased to $72 \mathrm{~h}$ in water restricted rats (Fig. 5, $D$ and $E$ ). The PCR products for V2 receptor decreased to $75.8 \pm 8.8 \%$ in $12 \mathrm{~h}$ ( $n=5$, vs control group), $66.3 \pm 9.4 \%$ in $24 \mathrm{~h}, 60.7 \pm 9.2 \%$ in 36 $\mathrm{h}, 53.8 \pm 7.9 \%$ in $48 \mathrm{~h}$, and $43.8 \pm 11.2 \%$ in $72 \mathrm{~h}$ in water restriction rat group. The values were corrected by the band intensity of GAPDH band intensity of the same sample.

\section{Discussion}

AVP is reported to reduce the glomerular ultrafiltration permeability coefficient $\left(K_{\mathrm{f}}\right)$ and decrease the glomerular filtration rate (33). It has been shown that AVP stimulates contraction of cultured glomerular mesangial cells via a rise in intracellular $\mathrm{Ca}^{2+}(34)$. This effect is considered to be through the Vla receptor $(19,34)$. It is not known, however, if the native glomerulus expresses the Vla receptor. In fact, no autoradiographic studies have demonstrated V1a specific glomerular binding on native renal tissue (7-10). The presence of the V2 receptor in glomerulus is not well established either. Imbert et al. (35) showed that $10^{-10} \mathrm{M}$ AVP produces a small but significant stimulatory effect on the adenylate cyclase activity in isolated rabbit glomeruli, but others did not $(36,37)$. Our data show that $\mathrm{V} 1 \mathrm{a}$, and not $\mathrm{V} 2$ receptor mRNA is expressed in rat glomerulus. Therefore, the action of AVP to influence glomerular function may be mediated by the V la receptor.

Only a few studies have been carried out to investigate AVP effect on proximal tubules. Binding studies (7-10) and microdissection studies $(12,14)$ had no positive results for AVP effect in proximal tubule. We could not detect V2 receptor mRNA from PCT or PST. The V1a receptor mRNA levels in
PCT and PST are very small compared with glomerulus or collecting ducts, and the physiological significance of this expression is unclear.

Imbert et al. (14) reported that there is a small but statistically significant cAMP increase induced by AVP in thin limbs. We detected a very low level of V1a and V2 mRNAs from IMTL, although it was impossible to discern whether the expression was in ascending or descending limbs. Physiological function of these receptor in thin limbs is unknown.

There is general agreement about the $\mathrm{V} 2$ receptors play an important regulatory role in the MTAL, but the possible role of $\mathrm{V}$ la receptors is uncertain. Autoradiographic studies using ${ }^{3} \mathrm{H}$ AVP and V1a and V2 antagonist show binding sites are present in outer and inner medulla (7-10). AVP has been reported to stimulate adenylate cyclase activities of MTAL of rabbit, rat, and mouse kidneys, but not of human and dog kidneys (12, 14, 38 ). In vitro microperfusion studies showed that AVP stimulates $\mathrm{NaCl}$ transport in rabbit, rat, and mouse kidneys $(39,40)$, possibly through the V2 receptor. Recently, Ammar et al. (11) reported, using V1a and V2 specific ligands, that not only V2 but also V1a receptor is present in MTAL. Our results show that both $\mathrm{V} 2$ and $\mathrm{V} 1 \mathrm{a}$ receptor mRNAs are indeed expressed in MTAL. Nitschke et al. reported that the V la receptor mediated intracellular $\mathrm{Ca}^{2+}$ increment in cortical thick ascending limbs (17). Prostaglandin $E_{2}$, which may be synthesized via V1a receptor (41), inhibits AVP-dependent stimulation of $\mathrm{NaCl}$ transport in mouse MTAL (42). Thus, V1a receptor may play some role in the self-inhibition of AVP in the MTAL.

Collecting tubules are the major target for physiological action of AVP in the kidney (43). AVP at the physiological concentration $10^{-11} \mathrm{M}$ can increase the hydro-osmotic water permeability and adenylate cyclase activity in the collecting tubules (18). Recently, AVP was reported to increase intracellular $\mathrm{Ca}^{2+}$ in CCD (16), IMCD (44), and cultured IMCD cells (45). Initial observation in CCD indicated that AVP evokes a transient rise in intracellular $\mathrm{Ca}^{2+}$, probably through Vla receptor (16). However more recent studies using IMCD cells showed that both AVP and 1-desamino-8-D-arginine vasopressin, on an equimolar basis, evoke a rise in intracellular $\mathrm{Ca}^{2+}$, suggesting the mediation of $\mathrm{V} 2$ receptor (45) or possibly heretofore unknown receptor type (46). Teitelbaum et al. reported that the increment of intracellular inositol 1, 4, 
5-trisphosphate evoked by AVP or V2 receptor agonist occurs via occupancy of the oxytocin receptor (47). Recently, Ando et al. (20) reported that luminal AVP interacts with the basolateral action of AVP, and suggesting that this luminal action of AVP may be mediated via V1a receptor. Thus, determination of the existence of $\mathrm{V} 1 \mathrm{a}$ receptor in the collecting duct is very important to understand overall AVP action in the collecting duct. Our data show not only the expression of the V2 receptor gene but also show V1a receptor mRNA in rat collecting ducts. In situ hybridization study revealed high levels of $\mathrm{V} 2$ receptor mRNA in collecting ducts, but no evidence of V1a receptor mRNA (48). The discrepancy about the expression of V1a receptor mRNA may be due to the different sensitivity between in situ hybridization and RT-PCR.

Our study revealed that the arcuate artery expresses mainly Vla receptor mRNA, as in other vascular tissue. Functional roles of the $\mathrm{V}$ la receptor in the arcuate artery have not yet been investigated.

Our results show that in the dehydrated state, V2 receptor mRNA expression decreases to $50-70 \%$ of the basal level, while $\mathrm{V}$ la receptor mRNA does not change significantly in collecting ducts. V2 receptor PCR products in IMCD decreased from 12 $\mathrm{h}$ water restriction and decreased further during $72 \mathrm{~h}$ water restriction. In contrast, Vla receptor PCR products in the IMCD did not change significantly during 72-h water restriction. Downregulation or desensitization of vasopressin receptors has been reported when the plasma AVP level is elevated (21-24). Steiner et al. (21) and Baddouri et al. (22) reported that water restriction causes the elevation of plasma AVP level and a decrease of AVP binding sites. The mechanism of receptor downregulation remains poorly understood. The mechanisms are likely to be complex and involve alterations in the rates of receptor internalization, degradation, assembly, processing, mRNA stability, and alterations in the rates of receptor gene transcription $(21,24,49,50)$. Our data suggest that some part of this downregulation may be caused by a decrease of the V2 receptor mRNA level.

We believe that our method gives a relative measure of the amount of specific V1a and V2 receptor mRNA initially present in the cells. It is possible to normalize mRNA values by the contents of DNA, protein, or number of cells. Because many physiological studies (i.e., microdissection or microperfusion studies) have expressed hormonal action per tubule length (2, $10,12-18,20,27,39,40,42,44)$, we expressed PCR products per tubule length to relate the data to physiological functions.

Protein synthesis is determined by both mRNA level and by the efficiency of mRNA transcription. The rate of Vla and V2 receptor mRNA translation has not been evaluated here, nor have the levels of protein expression been investigated. Therefore, it seems very difficult to speculate about the relationship between the amount of mRNA level and the number of receptors present in cell surface. The RT-PCR technique is so sensitive that some proteins may not be detectable in the cell despite the presence of mRNA according to RT-PCR (51). Thus the presence of V1a and V2 receptor mRNA does not imply necessarily the existence of its functional protein product in the nephron segments. In particular, it must be careful with regard to the presence of functional receptor protein, when we detect very small levels PCR product such as V1a receptor mRNA in PST and PCT.

In summary, our data show that mRNA coding for the two
AVP receptor subtypes are distributed differently along the nephron and renal vascular system, and that these mRNAs are regulated differently in response to the dehydrated state. These results are consistent with the view that the two type receptors may play different roles in modulating renal functions.

\section{Acknowledgments}

We thank Dr. Mark A. Knepper (Laboratory of Kidney and Electrolyte Metabolism; National Heart, Lung and Blood Institute, National Institutes of Health, Bethesda, MD) for critical reading of this manuscript and for his suggestions.

This work was partly funded by Grant-in-Aid for General Scientific 04454234 and 04670383 , and the Mochida Memorial Foundation for Medical and Pharmaceutical Research 1992.

\section{References}

1. Schor, N., I. Ichikawa, and B. M. Brenner. 1981. Mechanisms of action of various hormones and vasoactive substances on glomerular ultrafiltration in the rat. Kidney Int. 20:442-451.

2. Elalouf, J. M., A. di Stefano, and C. de Rouffignac. 1986. Sensitivities of rat kidney thick ascending limbs and collecting ducts to vasopressin in vivo. Proc. Natl. Acad. Sci. USA. 83:2276-2280.

3. Michell, R. H., C. J. Kirk, and M. M. Billah. 1979. Hormonal stimulation of phosphatidylinositol breakdown, with particular reference to the hepatic effects of vasopressin. Biochem. Soc. Trans. 7:861-865.

4. Morel, A., A. M. O'Carroll, M. J. Brownstein, and S. J. Lolait. 1992. Molecular cloning and expression of a rat Vla arginine vasopressin receptor. Nature (Lond.). 356:523-526.

5. Birnbaumer, M., A. Seibold, S. Gilbert, M. Ishido, C. Barberis, A. Antaramian, P. Brabet, and W. Rosenthal. 1992. Molecular cloning of the receptor for human antidiuretic hormone. Nature (Lond.). 357:333-335.

6. Lolait, S. J., A. M. O'Carroll, O. W. McBride, M. Konig, A. Morel, and M. J. Brownstein. 1992. Cloning and characterization of a vasopressin V2 receptor and possible link to nephrogenic diabetes insipidus. Nature (Lond.). 357:336339.

7. Dorsa, D. M., L. A. Majumdar, F. M. Petracca, D. G. Baskin, and L. E. Cornett. 1983. Characterization and localization of ${ }^{3} \mathrm{H}$-arginine ${ }^{8}$-vasopressin binding to rat kidney and brain tissue. Peptides. 4:699-706.

8. Van Leeuwen, F. W., E. M. van der Beek, J. J. van Heerikhuize, P. Wolters, G. van der Meulen, and Y.P. Wan. 1987. Quantitative light microscopic autoradiographic localization of binding sites labelled with $\left[{ }^{3} \mathrm{H}\right]$ vasopressin antagonist $\mathrm{d}\left(\mathrm{CH}_{2}\right)_{5} \mathrm{Tyr}(\mathrm{Me}) \mathrm{VP}$ in the rat brain, pituitary and kidney. Neurosci. Lett. 80:121-126.

9. Phillips, P. A., J. M. Abrahams, J. M. Kelly, V. Mooser, D. Trinder, and C. I. Johnston. 1990. Localization of vasopressin binding sites in rat tissues using specific V1 and V2 selective ligands. Endocrinology. 126:1478-1484.

10. Ammar, A., A. Schmidt, B. Semmekrot, S. Roseau, and D. Butlen. 1991. Receptors for neurohypophyseal hormones along the rat nephron: ${ }^{125}$ I-labelled $\mathrm{d}\left(\mathrm{CH}_{2}\right)_{s}\left[\mathrm{Tyr}(\mathrm{Me})^{2}, \mathrm{Thr}^{4}, \mathrm{Orn}^{8}, \mathrm{Tyr}-\mathrm{NH}^{9_{2}}\right]$ vasotocin binding in microdissected tubules. Pfluegers Arch. 418:220-227.

11. Ammar, A., S. Roseau, and D. Butlen. 1992. Pharmacological characterization of V la vasopressin receptors in the rat cortical collecting duct. Am. J. Physiol. 262:F546-F553.

12. Chabardes, D., M. Gagnan-Brunette, M. Imbert-Teboul, O. Gontcharevskaia, M. Montegut, A. Clique, and F. Morel. 1980. Adenylate cyclase responsiveness to hormones in various portions of the human nephron. J. Clin. Invest. 65:439-448.

13. Hebert, S. C., J. A. Schafer, and T. E. Andreoli. 1981. The effects of antidiuretic hormone (ADH) on solute and water transport in the mammalian nephron. J. Membr. Biol. 58:1-19.

14. Imbert, M., D. Chabardes, M. Montegut, A. Clique, and F. Morel. 1975. Vasopressin dependent adenylate cyclase in single segments of rabbit kidney tubule. Pfluegers Arch. 357:173-186.

15. Jaisser, F., L. Bugeon, M. Blot-Chabaud, J. P. Bonvalet, and N. Farman. 1989. Effects of AVP and dDAVP on PGE $_{2}$ synthesis in superfused cortical collecting tubules. Am. J. Physiol. 256:F1044-F1050.

16. Burnatowska-Hledin, M. A., and W. S. Spielman. 1989. Vasopressin V1 receptors on the principal cells of the rabbit cortical collecting tubule. J. Clin. Invest. 83:84-89.

17. Nitschke, R., U. Frobe, and R. Greger. 1991. Antidiuretic hormone acts via $\mathrm{V} 1$ receptors on intracellular calcium in the isolated perfused rabbit cortical thick ascending limb. Pfluegers Arch. 417:622-632. 
18. Morel, F. Sites of hormone action in the mammalian nephron. 1981. Am. J. Physiol. 240:F159-F164.

19. Jard, S., C. Lombard, J. Marie, and G. Devilliers. 1987. Vasopressin receptors from cultured mesangial cells resemble Vla type. Am. J. Physiol. 253:F41-F49.

20. Ando, Y., K. Tabei, and Y. Asano. 1991. Luminal vasopressin modulates transport in the rabbit cortical collecting duct. J. Clin. Invest. 88:952-959.

21. Steiner, M., and M. I. Phillips. 1988. Renal tubular vasopressin receptors downregulated by dehydration. Am. J. Physiol. 254:C404-C410.

22. Baddouri, K., D. Butlen, M. Imbert-Teboul, F. L. Bouffant, J. Marchetti, D. Chabardes, and F. Morel. 1984. Plasma antidiuretic hormone levels and kidney responsiveness to vasopressin in the Jerboa, Jaculus orientalis. Gen. Comp. Endocrinol. 54:203-215.

23. Landgraf, R., P. Szot, and D. M. Dorsa. 1991. Vasopressin receptors in the brain, liver and kidney of rats following osmotic stimulation. Brain Res. $544: 287-290$.

24. Birnbaumer, M., A. Antaramian, A. P. N. Themmen, and S. Gilbert. 1992. Desensitization of the human V2 vasopressin receptor. J. Biol. Chem. 267:11783-11788.

25. Moriyama, T., H. R. Murphy, B. M. Martin, and A. Garcia-Perez. 1990. Detection of specific mRNAs in single nephron segments by use of the polymerase chain reaction. Am. J. Physiol. 258:F1470-F1474.

26. Terada, Y., T. Moriyama, B. M. Martin, M. A. Knepper, and A. GarciaPerez. 1991. RT-PCR micro-localization of mRNA for guanylyl cyclase-coupled ANF receptor in rat kidney. Am. J. Physiol. 261:F1080-F1087.

27. Ujiie, K., H. Nonoguchi, and F. Marumo. 1990. Effects of ANF on cGMP synthesis in inner medullary collecting duct subsegments of rat. Am. J. Physiol. 259:F535-F538.

28. Fort, P., L. Marty, M. Picchaczyk, S. E. Sabrouly, C. Dani, P. Jeanteur, and J. M. Blanchard. 1985. Various rat adult tissues express only one major mRNA species from the glyceraldehyde-3-phosphate-dehydrogenase multigene family. Nucleic Acids Res. 13:1431-1442.

29. Maniatis, T., E. Fritsch, and J. Sambrook. 1989. Molecular Cloning: A Laboratory Manual. Cold Spring Harbor Laboratory, Cold Spring Harbor, NY.

30. Finney, M. 1989. In Current protocols in molecular biology. R. Brent, R. E. Kingston, D. D. Moore, J. G. Steidman, J. A. Smith, and K. Struhl, editors. Greens Publishing, New York. Units 15.7.

31. Sanger, F., S. Nicklen, and A. R. Coulson. 1977. DNA sequencing with chain-terminating inhibitors. Proc. Natl. Acad. Sci. USA. 74:5463-5467.

32. Ysewijn-Van Brussel, K. A. R. N., and A. P. De Leenheer. 1985. Development and evaluation of a radioimmunoassay for $\mathrm{Arg}^{8}$-vasopressin, after extraction with Sep-Pak ${ }^{\mathrm{C}} 18$. Clin. Chem. 31:861-863.

33. Dworkin, L. D., I. Ichikawa, and B. M. Brenner. 1983. Hormonal modulation of glomerular function. Am. J. Physiol. 244:F95-F104.

34. Bonventre, J. V., K. L. Skorecki, J. I. Kreisberg, and J. Y. Cheung. 1986. Vasopressin increases cytosolic free calcium concentration in glomerular mesangial cells. Am. J. Physiol. 251:F94-F102.

35. Imbert, M., D. Chabardes, and F. Morel. 1974. Hormone-sensitive adenylate-cyclase in isolated rabbit glomeruli. Mol. Cell. Endocrinol. 1:295-304.

36. Schlondorff, D., P. Yoo, and B. E. Alpert. 1978. Stimulation of adenylate cyclase in isolated rat glomeruli by prostaglandins. Am. J. Physiol. 235:F458F464.
37. Sraer, J., R. Ardaillou, N. Loreau, and J. D. Sraer. 1974. Evidence for parathyroid hormone sensitive adenylate cyclase in rat glomeruli. Mol. Cell. En docrinol. 1:285-194.

38. Ruggles, B. T., N. Murayama, J. L. Werness, S. M. Gapstur, M. D. Bentley, and T. P. Dousa. 1985. The vasopressin-sensitive adenylate cyclase in collecting tubules and in thick ascending limb of Henle's loop of human and canine kidney. J. Clin. Endocrinol. Metab. 60:914-921.

39. Wittner, M., A. di Stefano, P. Wangemann, R. Nitschke, R. Greger, C. Bailly, C. Amiel, N. Roinel, and C. de Rouffignac. 1988. Differential effects of ADH on sodium, chloride, potassium, calcium and magnesium transport in cortical and medullary thick ascending limbs of mouse nephron. Pfluegers Arch. 412:516-523.

40. Nonoguchi, H., K. Tomita, and F. Marumo. 1992. Effects of atrial natriuretic peptide and vasopressin on chloride transport in long- and short-looped medullary thick ascending limbs. J. Clin. Invest. 90:349-357.

41. Wuthrich, R. P., and M. B. Vallotton. 1986. Prostaglandin $E_{2}$ and cyclic AMP response to vasopressin in renal medullary tubular cells. Am. J. Physiol. 251:F499-F505.

42. Torikai, S., and K. Kurokawa. 1983. Effects of $\mathrm{PGE}_{2}$ on vasopressin-dependent cell cAMP in isolated single nephron segments. Am. J. Physiol. 245:F56F66.

43. Knepper, M., and M. Burg. 1983. Organization of nephron function. Am. J. Physiol. 244:F579-F589.

44. Star, R. A., H. Nonoguchi, R. Balaban, and M. A. Knepper. 1988. Calcium and cyclic adenosine monophosphate as second messengers for vasopressin in the rat inner medullary collecting duct. J. Clin. Invest. 81:1879-1888.

45. Ishikawa, S., K. Okada, and T. Saito. 1988. Arginine vasopressin increases cellular free calcium concentration and adenosine 3', 5'-monophosphate production in rat renal papillary collecting tubule cells in culture. Endocrinology. 123:1376-1384.

46. Maeda, Y., J. S. Han, C. C. Gibson, and M. A. Knepper. 1993. Vasopressin and oxytocin receptors coupled to $\mathrm{Ca}^{2+}$ mobilization in rat inner medullary collecting duct. Am. J. Physiol. 265:F15-F25.

47. Teitelbaum, I. 1991. Vasopressin-stimulated phosphoinositide hydrolysis in cultured rat inner medullary collecting duct cells is mediated by the oxytocin receptor. J. Clin. Invest. 87:2122-2126.

48. Ostrowski, N. L., S. J. Lolait, D. J. Bradley, A. O'Carroll, M. J. Brownstein, and W. S. Young III. 1992. Distribution of V1a and V2 vasopressin receptor messenger ribonucleic acids in rat liver, kidney, pituitary, and brain. Endocrinology. 131:533-535.

49. Catt, K. J., J. P. Harwood, G. Aguilera, and M. L. Dufau. 1979. Hormonal regulation of peptide receptors and target cell responses. Nature (Lond.). 280:109-116.

50. Collins, S., M. Bouvier, M. A. Bolanowski, M. G. Caron, and R. J. Lef kowitz. 1989. cAMP stimulates transcription of beta2-adrenergic receptor gene in response to short-term agonist exposure. Proc. Natl. Acad. Sci. USA. 86:48534857.

51. Hirono, A., and E. Beutler. 1989. Alternative splicing of human glucose-6-phosphate dehydrogenase messenger RNA in different tissues. J. Clin. Invest. 83:343-345. 